\title{
The Crisis of our Time and the End of the New "History"
}

\author{
Fabrizio Pezzani* \\ Department of Social and Political Sciences, Bocconi University, Italy
}

Submission: May 07, 2018; Published: October 31, 2018

*Corresponding author: Fabrizio Pezzani, Department of Social and Political Sciences, Bocconi University, Italy

\begin{abstract}
The issues raised on the congruency of the Nobel prizes awarded, the will of its founder, and the economic process are only part of a much more complex and deeper problem that constitutes the true genesis of the crisis of our time: an anthropological and not economic crisis. The debate on economics and its methods of study cannot be separated from a correct reading of history that in the long term tends to repeat itself, as G.B. Vico had envisioned; the nature of man never changes, constantly oscillating between Cain and Abel, and only pain leads man to wisdom. The single technical-rational thought makes us see the future as the only guarantee of success and we therefore cannot understand the correlations between the causes and effects in our history. We act as if the past had been erased and as if history had never manifested similar situations to those in which we find ourselves today.
\end{abstract}

The debates on the role of studies in economics, and finance, are broader and must be ascribed to a historical framework to understand how these have contributed to an acceleration in the change of a socio-cultural model that has collapsed but has its distant roots in the field of speculation. The change is rooted as far back as Kant, who with the utterance of self-doubt affirmed that reason rendered the finitude and absolute character (infinity) of freedom a starting point of German idealism and the historical materialism of Marx. The West entered the "tekhné" world and began to separate man from his soul, thereby establishing as "truth" only that which is tangible, observable, and measurable, and the sciences that explain this truth become themselves "truth".

This principle of truth has also been extended to economics, to its methods of study, and the role that we attribute it in defining the priorities of the founding values of society. The prizes, as previously noted, have helped change and legitimize the methods of study of a science that was born and remains an instrumental and social science but has ended up assuming the role of a moral science, namely teleological, to be studied as a positive and exact science. We have ended up exchanging the ends for the means, where man no longer defines the needs but the external system becomes dominant, independent of the man who becomes the means, an "economified" man. In short, we do not earn to live but live to earn and thereby life as a means can itself become a commodity. In the positive and exact sciences, however, the object of study is independent of the person who studies it - a reaction takes place because it responds to its intrinsic rationality - but in economics, the object of study - the search for the best combination of needs and scarce resources - is also an integral part of the emotional dimension of the individual addressing the problem.

Keywords: Economic; Social; Teleological; Human rights

\section{Introduction}

The time has come to understand that we are facing an anthropological and not economic crisis as it is reductively defined; it is the failure of a socio-cultural model that has erased the fundamental human rights inscribed in 1948. The response to the crisis [1] as anthropological is in understanding the cultural and historical path that has brought us to chaos, overthrowing the dominant paradigm, to place man and society at the centre of our interests as an end and to bring economics back to its natural role as a means. The technical culture, master of the world, as defined by Emanuele Severino, has unnaturally transformed economics as a social science into an exact science; in the exact sciences we study the relationships between measurable things to define universal laws, but in the social sciences, such as economics, we study relationships between men where human subjectivity does not allow defining universal laws [2-4].
Von Hayek in his Nobel acceptance speech in 1974 denounced the serious mistake that would pave the way for rational finance and speculative markets distant from the real world; but he remained unheard. The extreme financialization of the real economy became deeply rooted since 1971 when Nixon unilaterally declared the end of the dollar's convertibility into gold. Let us look at the sequence of events. In 1945, after the drama of war, rules were defined to stabilize markets and exchange rates; the printing of paper money that has no value was tied to a defined quantity of a real good and the "gold exchange standard" was launched - 36 \$ for every ounce of gold. In that period that lasted until the beginning of the 70s, we had a fixed exchange rate system that favoured unprecedented economic and social growth [5-7]. In 1971, the point of maximum social cohesion in the US coincided exactly with the point of lower inequality in income, providing evidence that the two aspects are closely related and that only a cohesive and just society can lead to solid economic development [8] (Figures 1 \& 2). 


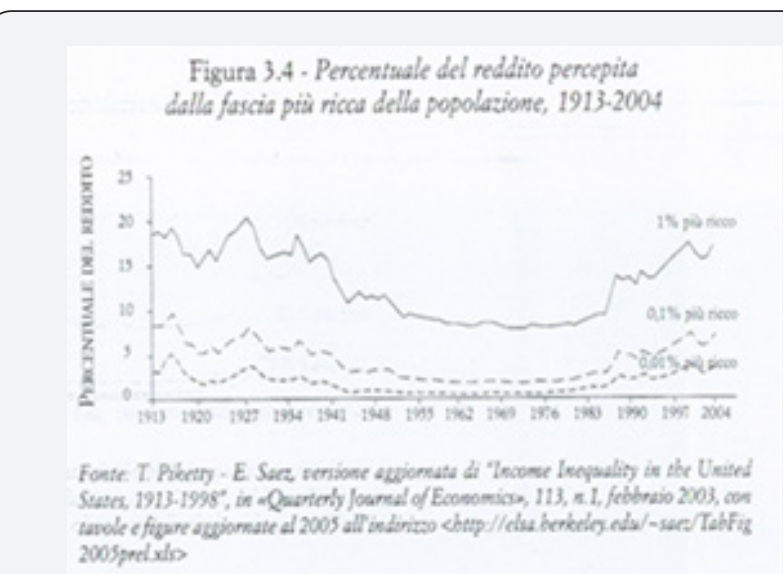

Figure 1: In 1971, the point of maximum social cohesion in the US coincided exactly with the point of lower inequality in income.

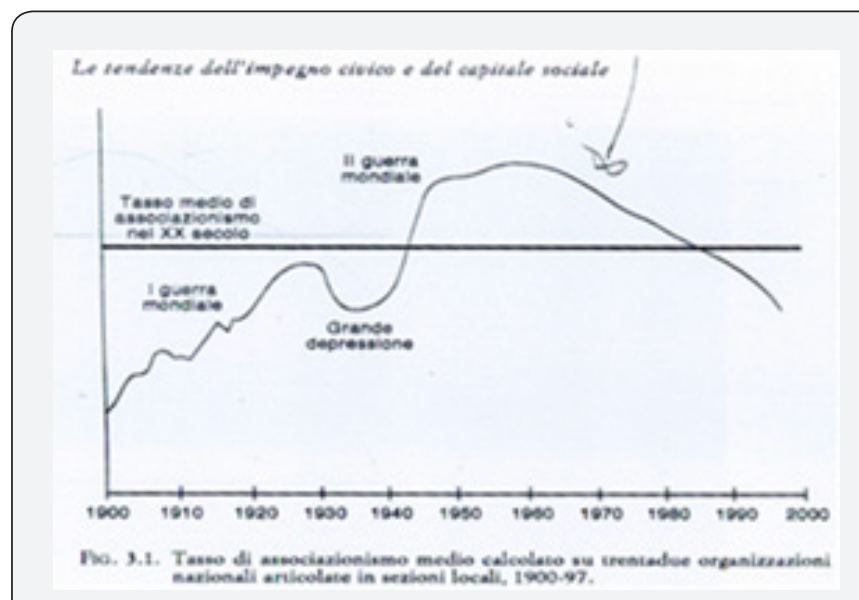

Figure 2: Providing evidence that the two aspects are closely related and that only a cohesive and just society can lead to solid economic development.

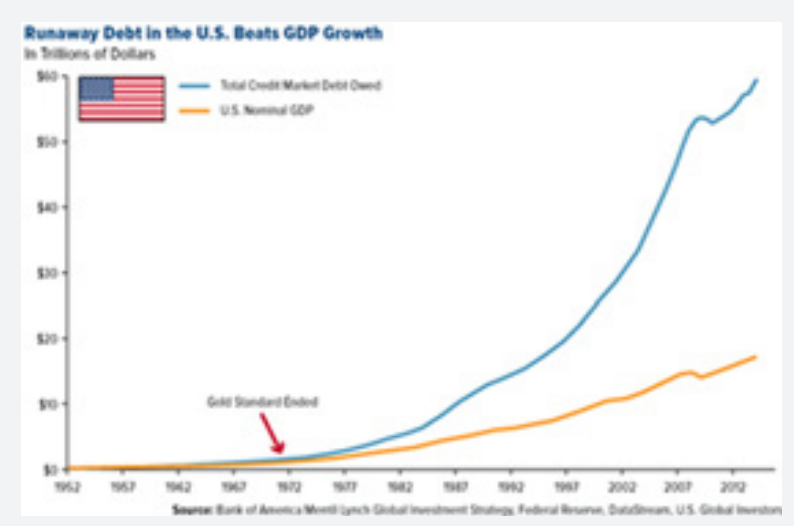

Figure 3: All the positive curves of the "golden age" have an inflection and deteriorated between 1971 and 1974 because of Nixon's decision.

All the positive curves of the "golden age" have an inflection and deteriorated between 1971 and 1974 as a result of Nixon's decision; from the "gold exchange standard" we would go to the "petrodollar exchange standard" and to a system of flexible exchange rates, and we would suffer terrible inflation that went from $4.4 \%$ to $24 \%$, paving the way for today's drama of uncontrolled finance, as we see in following graphs (Figures 3-6).
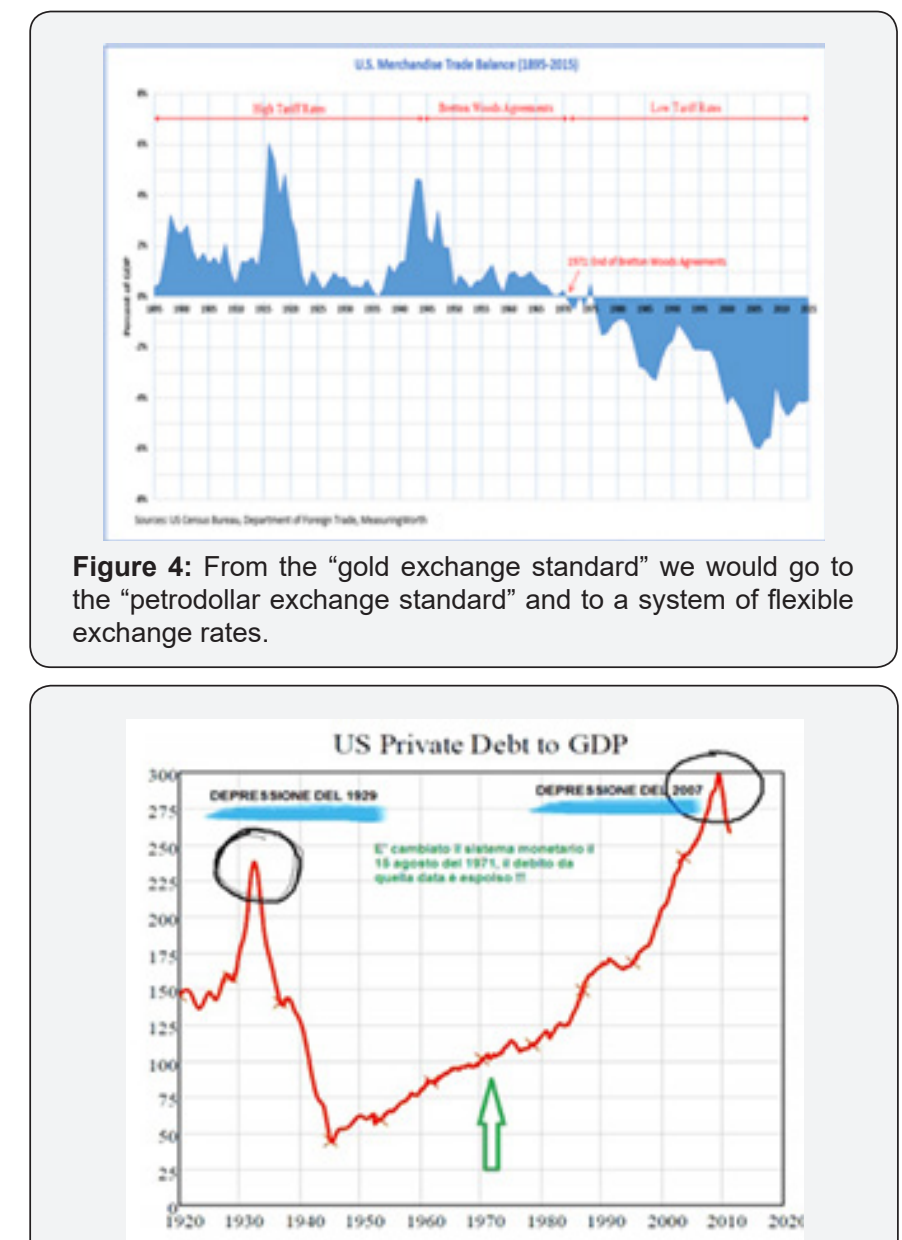

Figure 5: We would suffer terrible inflation that went from $4.4 \%$ to $24 \%$, paving the way for today's drama of uncontrolled finance.

\section{Inequality in Selected Countries \\ Income shave of the top 1 percent of earners}
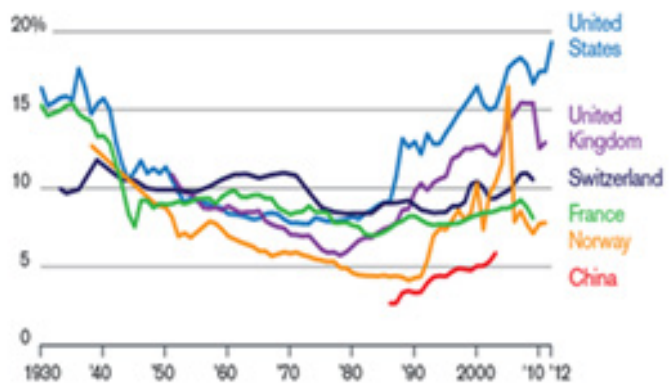

Figure 6: Italy would suffer the influx of petrodollars, which began to drain the efforts made in the post-war period to bring the country among those with the highest growth rate.

Italy would suffer the influx of petrodollars, which began to drain the efforts made in the post-war period to bring the country among those with the highest growth rate; the price of oil per barrel went from $\$ 1.40$ to $\$ 40$, and the dollar/lira exchange rate 
after 25 years of the fixed exchange rate of 624/5 lira for every dollar to 2450 lira for a dollar in just 9 years: it was to be the first financial war, but in reality a third World War not fought with traditional means but with the power of the financial markets [911] (Figures 7 \& 8).

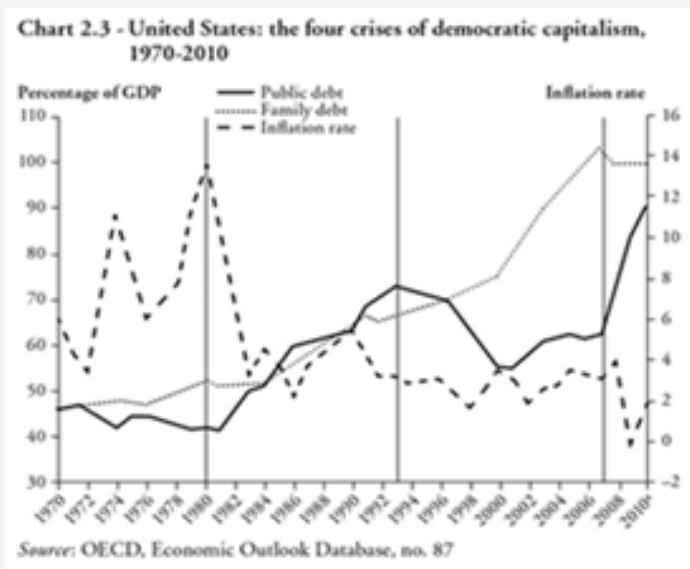

Figure 7: The price of oil per barrel went from $\$ 1.40$ to $\$ 40$, and the dollar/lira exchange rate after 25 years of the fixed exchange rate of $624 / 5$ lira for every dollar to 2450 lira for a dollar in just 9 years.

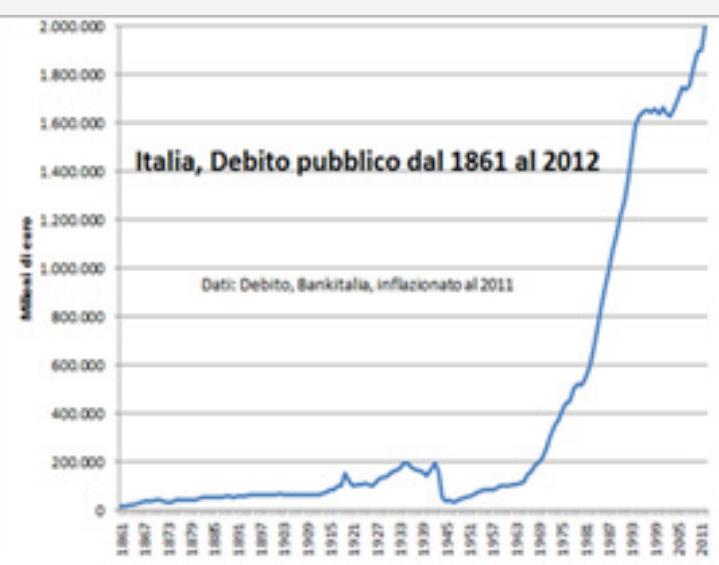

Figure 8: It was to be the first financial war, but, a third World War not fought with traditional means but with the power of the financial markets.

The separation of paper money from the real finite created two incompatible systems: the infinite and non-measurable of currency that would be totally deregulated, and the finite and measurable of the real world that became fictitiously subordinate to the former [12,13]. Everything changes, and the neoliberal model taken as an end justifies unlimited personal accumulation and the legitimisation of human aggression. Everything becomes finance and pure speculation in virtue of a paper currency that, detached from finite bonds and the real world, becomes infinite and would turn into "macro-usury" capable of keeping companies and entire countries in check $[14,15]$. Infinite finance without constraints can be studied with exact mathematical models generating the false idea that financial markets are rational and never err in the allocation of wealth. The study of financeeconomics severs the ties with the humanistic sciences, becoming a pure arithmetic calculation far from reality but assumed as incontrovertible truth thanks to the many Nobel prizes assigned to economics, unfounded but serving higher interests [16-18].

The Role of the Humanistic Culture that the Academy has Lost

Since the late 60s, in awarding the prizes for literature, economics, and peace - the three prizes with the most obvious contradictions - the anomalies have become more apparent, favouring a cultural model and its interests that have brought us to the true crisis of our time, the anthropological crisis that we still refuse to see. Since 1969, when the first prize for economics was awarded, American scholars have won the lion's share [1921]. In the 44 years of Nobel prizes in economics, one or more than one has been awarded the prize 41 times: a monoculture without inconsistency and change 41 times out of 44 . Only in three years did they not win: 1969, 1974, and 1988.

The trend was accentuated after the fall of the Berlin Wall when the awards rained down on economics scholars who defined the financial markets as rational and exact without possibility of error [22]. Finance has become a sort of hegemonic weapon over States able to exert pressure on the policies of individual States and global choices. Wealth is thus created without States and States without wealth, a model of an individualistic and conflictual society in which moral sense is subservient to personal interests and the strongest command. Yet, is the soul of this cultural model able to inspire feelings such as kindness, altruism, solidarity, respect for humankind, in short, the ideals that Alfred Nobel sought?

The answer can be found with disarming evidence in the prizes awarded for literature. In fact, since the end of the $60 \mathrm{~s}$, the United States that seemed omnipotent has only won one real prize in literature. Morrison, in 94, expressed the racial pain of coloured minorities, now majorities; Bellow in 76 and Singer in 78, were the expression of the European culture where they had lived for a long time before moving to the United States [23-25]. The other awards over the years have been divided among different countries where the type of wellbeing expressed by the economy was absent or irrelevant - for example, Ireland, Peru, Chile, Saint Lucia, Poland, Romania, Greece... The two cultural models are opposed, without the possibility of dialogue and sharing because the interests of economics and finance put the maximization of self-interest in first place and not the "common good", exactly what Alfred Nobel wanted to avoid. The legitimacy of the single thought has suffocated the imagination and the universal values of freedom, equality and solidarity. In the words of Pascal, "l'esprit de finesse" was finally separated from the "esprit de geometrie", but rational man arrived last in the race. Everyone is responsible, albeit in different ways, because everyone contributed, even in silence, to ascribing the value of incontrovertible truth to these positions [26]. 
The technical-rational culture of the post-modern era prepared by the field of speculation since the Enlightenment with Kant, Hegel, and then Marx transformed economics into an exact science by studying only what is measurable. The materialistic objectives promoted by capitalism and liberalism assumed as an end and not a means contributed to the creation of a society aimed at achieving self-interest at the expense of the common good and the normalization of unlawful behavior [27]. This has increasingly forced dominant interests to legitimize such studies with the Nobel Prizes that elevated their achievement to ultimate truth but not the real sciences, eventually disrupting the system of social relations, because the dogma has become 'live to earn' and not vice versa. This year once again, in rewarding the disrupting sociocultural model of human society, the Academy has deeply betrayed the noble intentions of Alfred Nobel.

Understanding the deviations of economic studies transformed from a social and moral science into a merely quantitative, exact, and positive science requires understanding the causes that favour the interests of the few at the expense of everyone else. At the end of World War II, the global dramas led to defining the universal and "inalienable" rights of man and the technical operational rules of economics in such a way as to guide global policymakers to restore the dignity of man as a person and not as he is in fact today.

The Time of Finance: Human Greed Manages the World

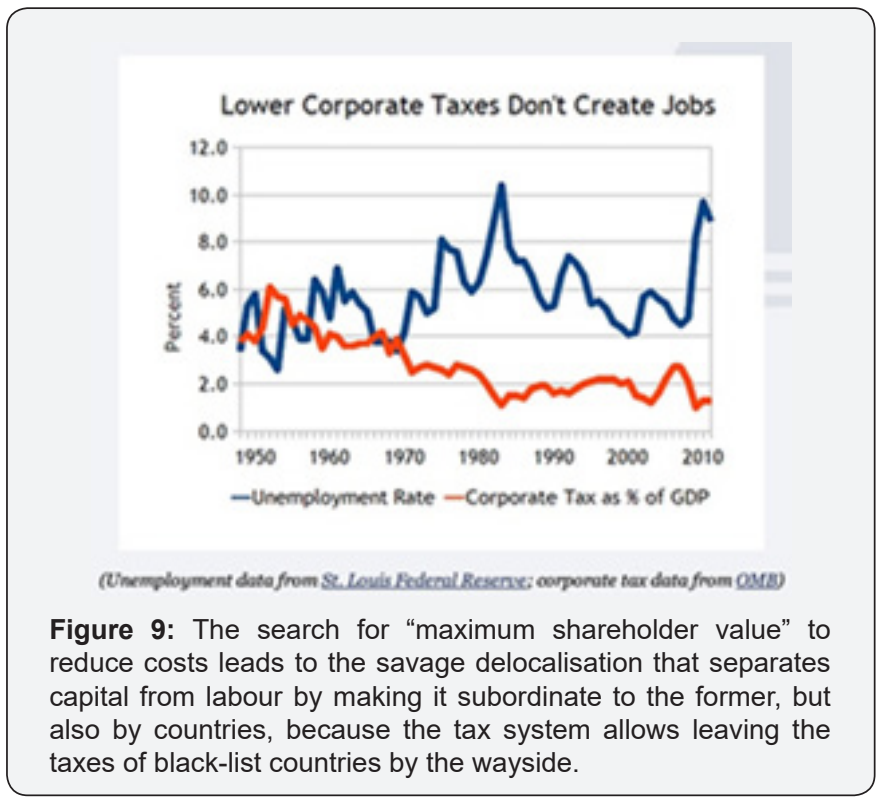

Everything becomes finance and everything is justified as "strictly scientific" by the Nobel Prize in Economic Sciences; the pursuit of maximum personal gains justifies the normalization of illicit behaviours, everything is played in a short or very short term logic in an infinite exchange at high speed where computers decide according to algorithms based on the nothingness of infinite finance, without anything underlying it. Stock exchanges become infinite casinos without rules or maximum profit in an amoral logic because those deciding in finance never pose themselves the problem of the consequences of their actions, and since it is always man who engages in illicit behaviours they become a practice of life that extends to young people who lose their identity in the confusion of value, becoming plankton at the mercy of the waves. Society without values and a humanistic culture become territories in which it is difficult to live and the individualism pursued as an end eradicates the first impulse that dictates the human spirit, that of aggression and lack of attention to others; "societas" understood as an alliance is transformed into the monster of the "bellum contra omnes", the war of all against all, and everything becomes lawful [28].

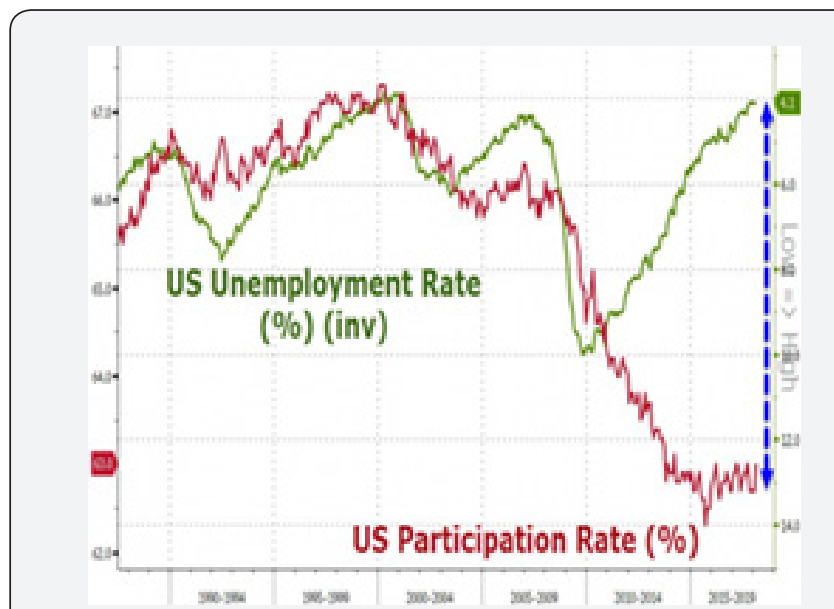

Figure 10: We passively forget our history and become victims of this finance by transforming ourselves from the best creative artisans in the world into losing and checkmated financiers.

The search for "maximum shareholder value" to reduce costs leads to the savage delocalisation that separates capital from labour by making it subordinate to the former, but also by countries, because the tax system allows leaving the taxes of blacklist countries by the wayside (Figures $9 \& 10$ ). We passively forget our history and become victims of this finance by transforming ourselves from the best creative artisans in the world into losing and checkmated financiers; the social system disintegrates and fragments, social ills explode, and the old solidarity of our people becomes a war of all against all with growing moral degradation because it justifies living to earn and not vice versa. Locust finance must be brought under strict control, eliminating the speculative derivatives that have emptied the reserves, redefining the boundary between business and commercial banks, but also with a return to the convertibility of currency into gold, as China, Russia, and other emerging countries close to creating an alternative financial system to the dollar are doing, because the new balances of power allow it [29].

The challenge of our time is to rebuild a cohesive social system, recovering the solidarity of our familial roots and the small and medium-sized businesses that constitute the backbone of our nation over time, and recover the pride of our history and autonomy that allows us to decide without having a gun pointed at our heads. History, forgotten by a society that lives only in the present, teaches over the millennia that a society can live only on solid family roots and maintain a trade-off between the 


\section{Annals of Social Sciences \& Management studies}

agricultural world that generates solidarity and the urban world that creates individualism. Will we be able to understand the lessons of history? This is the enigma we have before us [30-31] (Figure 11).

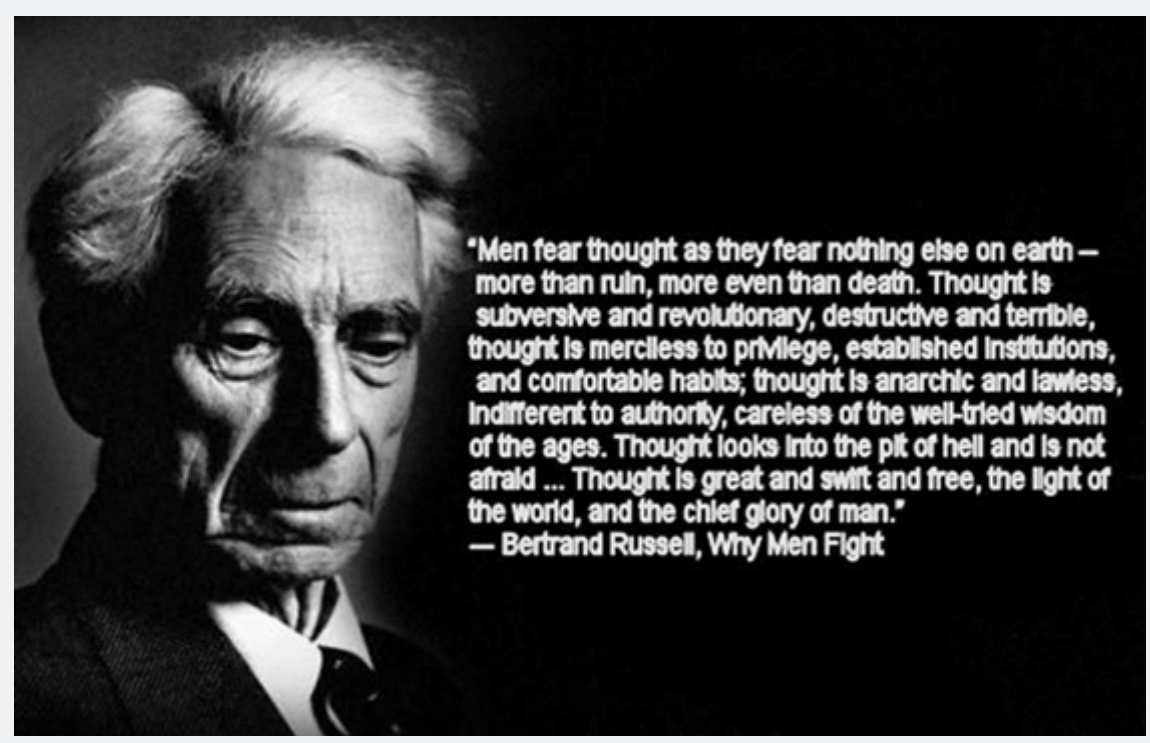

Figure 11: The challenge of our time is to rebuild a cohesive social system, recovering the solidarity of our familial roots and the small and medium-sized businesses that constitute the backbone of our nation over time.

\section{References}

1. Posner R (2010) The crisis of capitalist democracy. Egea-UBE, Milan Italy.

2. Aristotele (2000) Etica Nicomachea [Nicomachean Ethics]. Bompiani: Milan, Italy.

3. Chomsky N (2006) Failed States: The Abuse of Power and the Assault on Democracy. Il Saggiatore: Milano.

4. De Honoré B (1892) Illusions Perdues [Lost Illusions]. Calmann Lévy: Paris, France.

5. Galbraih JK (1955) The Great Crash: 1929. Houghton Mifflin: Boston, USA.

6. Sigmund F (1971) The Discomforts of Civilization. Bollati Boringhieri: Turin, Italy.

7. Sigmund F (1971) The Future of Illusion. Boringhieri: Turin, Italy.

8. Guardini R (1954) The End of the Modern World. Morcelliana: Brescia, Italy.

9. Keynes JM (1991) Economic Possibilities for Our Grandchildren. Bollati Boringhieri: Turin, Italy. P. 321-332.

10. Keynes JM (1923) The End of Laissez Faire. MacMillan Publishers, London. P. 272-294.

11. Sorokin P (1941) The Crisis of our age. EP Button \& Co: New York, USA. 12. Keynes JM (1933) Essays in Persuasion. MacMillan, London, UK.

13. Krugman P (2009) How Did Economics Get It So Wrong? The N.Y. Magazine, New York, USA

14. Pezzani F (2008) The Lucidity Pact. UBE: Milan, Italy.
15. Pezzani F (2011) Cooperative Competition. Egea-UBE: Milan, Italy.

16. Pezzani F (2016) The Nobel Prize for mythical finance and Colombo's egg. Business and Economic Journal.

17. Pezzani F (2016) Independence Day and forgotten equality. Business and Economic Journal.

18. Pezzani F (2017) The gold exchange standard and the magic trap of paper money. Journal of Accounting, Finance and Auditing 5(4): 23-32.

19. Pezzani F (2017) Once upon a time in America and the end of the American dream. Journal of Socialomics.

20. Pezzani F (2017) Society the foundation of the economy. We need a sociocultural revolution. Scholar's Press: Germany.

21. Prigogine I (1996) La fin des certitudes. Temps, chaos et les lois de la nature. Odile Jacob, Paris.

22. Putnam R (2004) Social capital and individualism. Il Mulino, Bologna, Italy.

23. Russell B (2009) The scientific outlook. Rome-Bari, Laterza, Italy.

24. Schlesinger MA (2010) The age of Jackson. Lee Spilberg, New York.

25. Sen A (2010) The theory of moral sentiment. Penguin.

26. Severino E (2002) Techne. The roots of violence. Rizzoli: Milano, Italy.

27. Sorokin P (1941) Social and cultural dynamics. Utet: Turin, Italy.

28. Toynbee AJ (1949) Civilization on trial. Bompiani: Milan, Italy.

29. Toynbee AJ (1977) Mankind and mother earth. Garzanti: Milan, Italy.

30. Vico G (1725) La scienza nuova, [The New Science]. Napoli.

31. Zygmunt B (2005) Liquid Life. Laterza: Bari, Italy. 
This work is licensed under Creative Commons Attribution 4.0 License DOI: 10.19080/ASM.2018.02.555582

\section{Your next submission with Juniper Publishers} will reach you the below assets

- Quality Editorial service

- Swift Peer Review

- Reprints availability

- E-prints Service

- Manuscript Podcast for convenient understanding

- Global attainment for your research

- Manuscript accessibility in different formats

( Pdf, E-pub, Full Text, Audio)

- Unceasing customer service

Track the below URL for one-step submission https://juniperpublishers.com/online-submission.php 